\begin{abstract}
Hanna K. Lappalainen ${ }^{1,2,9}$, Irina Bashmakova ${ }^{1}$, Pavel Alekseychik ${ }^{1}$, Alla Borisova ${ }^{1}$, Nuria Altimir ${ }^{1}$, Mikhail Arshinov ${ }^{3}$, Boris Belan ${ }^{3}$, Gennadii Matvienko $^{3}$, Pavel Konstantinov ${ }^{4}$, Sergey Chalov ${ }^{4}$, Nina Zaitseva ${ }^{5}$, Jaana Bäck ${ }^{6}$, Tuukka Petäjä ${ }^{1,9}$, Timo Vesala ${ }^{1}$, Julia Kurbatova ${ }^{7}$, Nikolay Kasimov ${ }^{4}$, Aleksander Baklanov ${ }^{8}$, Vladimir Melnikov ${ }^{9,10}$, Pertti Hari $^{6}$, Sergej Zilitinkevich ${ }^{1,2,9,11}$, Markku Kulmala ${ }^{1,9}$
\end{abstract}

\title{
ESTABLISHING THE PAN-EURASIAN EXPERIMENT (PEEX) LAND-ATMOSPHERE IN SITU OBSERVATION NETWORK ACROSS THE NORTHERN EURASIAN ARCTIC-BOREAL REGIONS - INTRODUCTION TO THE RUSSIAN STATIONS' METADATA ENQUIRY
}

\begin{abstract}
Pan-Eurasian Experiment (PEEX) initiative (https://www.atm.helsinki.fi/peex/), initiated in 2012, is an international, multidisciplinary, multiscale program focused on solving interlinked global challenges influencing societies in the Northern Eurasian region and in China. As a part of the program, PEEX is aimed to establish an in situ observation network, which would cover environments from the Arctic coastal regions, tundra to boreal forests, from pristine to urban megacities. The PEEX network will be based on two components: ( $i$ ) the existing stations activities and (ii) establishing new stations. The upgrading plans of the existing stations as well as the new stations will be based on a SMEAR (Stations for Measuring Earth surface - Atmosphere Relations) concept. The development of the coordinated, comprehensive PEEX observation network is contributing to the sustainable development of the Northern Eurasian regions. It is aimed at providing quantified information on climate relevant variables for the research communities and for constructing services, such as early warning systems, for the society.
\end{abstract}

\section{KEYWORDS:}

observation systems, in situ observations, early warning, climate predictions, land atmosphere interactions, atmospheric composition, photosynthesis, boreal forests, Stations for Measuring Earth surface - Atmosphere Relations, SMEAR concept

\section{INTRODUCTION}

The boreal forests dieback and the permafrost-tundra loss of the Northern Hemisphere have been indicated as a policy relevant tipping points of the Earth system, which could exhibit threshold-type behavior in response to anthropogenic climate forcing [Lenton et al., 2008]. To better understand the processes, feedbacks and biogeochemistry related to these critical areas we need more measurements on the relevant atmospheric variables such as $\mathrm{CO}_{2}, \mathrm{CH}_{4} \mathrm{CO}, \mathrm{O}_{3}$, aerosols (incl. black carbon) and on the variables describing the ecosystem biological activity (GPP, NEE) [Paris et al.,

\footnotetext{
${ }^{1}$ Dept. of Physics, University of Helsinki, Finland; $e$-mail: hanna.k.lappalainen@ helsinki.fi; alla.borisova@helsinki.fi

${ }^{2}$ Finnish Meteorological Institute, Helsinki, Finland

${ }^{3}$ Institute of Atmospheric Optics, Tomsk 634021, Russia

${ }^{4}$ Lomonosov Moscow State University, Faculty of Geography, Moscow 119991, Russia

${ }^{5}$ Dept. of Earth Sciences, Russian Academy of Sciences, Russia

${ }^{6}$ Dept. of Forest Sciences, University of Helsinki, Finland

${ }^{7}$ A.N. Severtsov Institute of Ecology and Evolution (RAS), Russia

${ }^{8}$ World Meteorological Organization, 1211 Genève, Switzerland

${ }^{9}$ Tyumen State University, 625003 Tyumen, Russia

${ }^{10}$ Tyumen State University, 625003 Tyumen, Russia

${ }^{11}$ Dept. of Radiophysics, Nizhny Novgorod State University, Russia
} 
2008; Sasakawa et al., 2013; Kozlova et al., 2008, Kulmala et al., 2011]. This type of comprehensive ground-based measurements together with the remote sensing data over the currently underdocumented regions of Siberia and Arctic coastal line are also needed to validate different types of land and atmospheric models.

In 2012, when the PEEX Program [Kulmala et al., 2015, 2017; Lappalainen et al., 2014, 2017, https://www.atm.helsinki.fi/peex/] was initiated, it was evident that one of the main focus areas of interests would be the filling of the observational gap, especially over the Siberian region, and the development of the coordinated in situ observation networks across the Northern Eurasian region and in China [Kulmala et al., 2016]. The backbone of the station network is based on the existing atmospheric, biosphere - ecological or urban stations. The first step towards a coordinated, comprehensive observation network is an overview of the measurement capacity of the existing stations. After having detailed information, the station metadata, it would be also possible to make the station specific upgrading plans and having added new instruments and measured variables to the observing program of the station.

The collection of the preliminary information of the existing stations activities started in 2012 . The first inventory on over 200 in situ stations operating in the Arctic and Subarctic Eurasian regions was conducted by the Russian Academy of Sciences (RAS) and Moscow State University together with the University of Helsinki [Alekseychik et al., 2016]. Based on the first inventory we started a collection of more detailed information, called "station metadata". A station metadata, the detailed descriptions of measured variables and the observation site, enables one to categorize the stations in a systematic manner and to connect them to international observation networks, such as WMO-Global Atmospheric Watch Program, China Ecosystem Network (CERN), and carry out standardization of data formats. Here we introduce the current state of the station metadata work in Russia.

\section{MATERIALS AND METHODS OF RESEARCH}

For collecting metadata information from the Russian stations we drafted out a "metadata enquiry", which has been sent, as of today, to over 60 Russian stations. A metadata enquiry is asking information on station's facilities, environments, on atmospheric, ecosystem measurements with a specific focus on different surfaces such as forest, lake, peatland, and urban. Furthermore, information is asked on data collections and their availability for external users, on collaboration and participation in different networks such as Carbon Flux network. We have also set up a relation database for archiving the collected station metadata and for carrying out comprehensive map based analysis on different variables and their geographical coverage across Russian Arctic - boreal regions.

The metadata enquiry and the questions are compiled basing on the measurement ensemble carried out at the SMEAR-II station (Station for Measuring Atmospheric Ecosystem Relation, $61^{\circ} 51^{\prime} \mathrm{N}, 24^{\circ} 17^{\prime} \mathrm{E}$ ) in Finland, and currently called "SMEAR Measurement Concept" (APPENDIX1). All the station carries out around year measurements of 1200 variables in 24/7 and is a qualified flagship measurement station participating in the Integrated Carbon Observation System (ICOS) network [www.icos-infrastructure.eu/] and European Research Infrastructure for the observation of Aerosol, Clouds, and Trace gases (ACTRIS) [www.actris.eu] as well as in The Long Term Ecological Research (LTER) Network and International Network for Terrestrial Research and Monitoring in the Arctic (INTERACT2).

The SMEAR II station is the most comprehensive station investigating biosphere-atmosphere interactions and atmospheric processes in the world and is the prototype of the flagship station for the PEEX observation network. The main components of SMEAR II are $127 \mathrm{~m}$ tall mast instrumented with meteorological measurements and gas profiles (7 levels), systems for monitoring physical, optical and chemical properties of aerosols, air ions and high resolution mass spectrometry for atmospheric chemistry, instrumentation for monitoring tree and soil functioning and radiation, two instrumented mini water catchments, two above-canopy and one sub-canopy eddy covariance 
(EC) measurement setups for ecosystem-scale biosphere-atmosphere exchange of GHGs and SLCFs. Emissions of $\mathrm{CO}_{2}$ and volatile organic compounds from the biosphere are monitored with various enclosure setups. Additional flux measurements are carried out at nearby wetland, Siikaneva fen. The longest time series in Siikaneva has been $\mathrm{CO}_{2}, \mathrm{H}_{2} \mathrm{O}$ and $\mathrm{CH}_{4}$ fluxes - since 2005. The auxiliary measurements include meteorological variables, peat temperature, water table depth and oxygen concentration.

\section{PRELIMINARY RESULTS OF RESEARCH AND DISCUSSION}

The Russian station metadata collection will be carried out in 2016-2017. So far our database covers metadata over 50 stations. Metadata has been received from stations such as NESS “Chersky" 68,64 N. 161,39E, Tiksi, 71.586 N, 128.77E, Belyy 73.335N, 70.075 E, Mukhrino Field Station, 60.54N, 68.42 E, Seida Vorkuta, 67.05N, 62,92E, Heiss Island, 80.60N, 58,03E, Zvenigirod 55.695N, 36.775E and SMEAR - Fyodorovskoe, 56.461N, 32.922E. Basing on the metadata inventory PEEX will publish a station catalogue introducing the measurements and contact information of the "Russian stations - PEEX collaboration network". The aim of the catalogue is to promote the research collaboration, indicate the station as partner in Russian stations - PEEX collaboration network and to give positive visibility to the station activities.

The map based analysis of the station metadata, preliminary scheduled to take place in 2018, will give guidelines and frameworks for detailed planning of the PEEX observation network such as optimal locations of different atmospheric - ecosystem measurements. Furthermore, it will demonstrate the observational gaps in a comprehensive and systematic way and provide background information for the specific upgrading plans such as new instrumentation needed for capturing specific events related to long-term atmospheric pollution or epidemical dispersion. The upgrading plans would be based on a SMEAR concept, the measurement theory and techniques as a result of a 20 year development at the SMEAR-II flagship station situated in Hyytiälä, Finland [Hari et al. 2017]. The options for upgrading the existing station network or building new stations based on SMEAR concept is under evaluation. Also some other relevant measurements to be included in the coordinated monitoring program are under consideration such as borehole data relevant to permafrost monitoring. The most active partners here have been Tyumen State University, A.N. Severtsov Institute of Ecology and Evolution (RAS), Tver State University and Moscow State University.

\section{CONCLUSIONS}

The comprehensive observation network is a crucial tool for environmental monitoring and is contributing to the sustainable environmental, economic and social development of the Northern Eurasian regions under changing climate. PEEX recognizes the unique opportunity to explore cooperation with all exiting ecosystem, atmospheric and meteorological stations. PEEX has capacity and know-how to establish an observation framework for solving environmental problems in the Northern Eurasia, and to become a community of shared interests. PEEX research outcome and observation activities and the new methodological concepts are providing new information not only for the climate policy making on a global scale but also for the regional infrastructure planning, urban design, construction of early warning systems (natural hazards), for the mitigation and adaption planning. Thus PEEX is aimed at deepening the collaboration with the European, Russian, Chinese and global partners to maximize the impact of the PEEX infrastructure development in the climate policy relevant processes. The key partners and stakeholders here are International Institute for Applied Systems Analysis (IIASA), Digital Earth, Future Earth, Arctic Council Sustainable Arctic Observation Network (SAON), WMO and Group of Earth Observation (GEO) - GEOCRI Cold Regions Initiative the in situ component. 


\section{ACKNOWLEDGEMENTS}

We would like to acknowledge the following support or funding from the following bodies: the NordForsk Nordic Centre of Excellence of CRAICC (No 26060); Nordforsk CRAICC-PEEX (amendment to contact 26060) and CRAICC-CRUCIAL (amendment to contact 26060), EU project INTAROS (2017-2012).

\section{REFERENCES}

1. Alekseychik P., Lappalainen H.K., Petäjä T., Zaitseva N., Heimann H., Laurila T., Lihavainen H., Asmi E., Arshinov M., Shevchenko V., Makshtas A., Dubtsov S., Mikhailov E., Lapshina E., Kirpotin S., Kurbatova Yu., Ding A., Guo H., Park S., Lavric J.V, Reum F., Panov A., Prokushkin A., Kulmala M. Ground-based station network in Arctic and Subarctic Eurasia: an overview, J. Geography Environment Sustainability, 2016.

2. Hari P., Petäjä T., Bäck J., Kerminen V-M., Lappalainen H.K., Vihma T., Laurila T., Viisanen Y., Vesala T., Kulmala M. Conceptual design of a measurement network of the global change, Atmos. Chem. Phys., 16, 1017-1028, 2016, http://www.atmos-chemphys.net/16/1017/2016/; doi:10.5194/acp-16-1017-2016.

3. Kozlova E. A., Manning A. C., Kisilyakhov Y., Seifert T., Heimann M. Seasonal, synoptic, and diurnal-scale variability of biogeochemical trace gases and $\mathrm{O}_{2}$ from a $300-\mathrm{m}$ tall tower in central Siberia, Global Biogeochem. Cycles, 22, GB4020; doi:10.1029/2008GB003209, 2008.

4. Kulmala M. et al. Pan-Evrazijskij ehksperiment (PEEX) v Rossii: perspektivy nauchnogo sotrudnichestva [Pan-Eurasian experiment (PEEX) in Russia: prospects for scientific cooperation], Vestnik Moskovskogo universiteta, Ser. 5. Geogr., 2017, N 1.

5. Kulmala M., Lappalainen H.K., Petäjä T., Kerminen V-M., Viisanen Y., Matvienko G., Melnikov V., Baklanov A., Bondur V., Kasimov N., Zilitinkevich, S. Pan-Eurasian Experiment (PEEX) Program: Grant Challenges in the Arctic-boreal context, J. Geography Environment Sustainability, 2016.

6. Kulmala M., Lappalainen H.K., Petäjä T., Kurten T., Kerminen V-M., Viisanen Y., Hari P., Bondur V., Kasimov N., Kotlyakov V., Matvienko G., Baklanov A., Guo H., Ding A., Hansson H-C., Zilitinkevich S. Introduction: The Pan-Eurasian Experiment (PEEX) - multidisciplinary, multi-scale and multi-component research and capacity building initiative, Atmos. Chem. Phys., 15, 13085-13096, 2015; doi:10.5194/acp-15-13085-2015.

7. Kulmala M., Lappalainen H.K., Bäck J., Laaksonen A., Nikinmaa A., Riekkola M-L., Vesala T., Viisanen Y., Aalto T., Boy M., Dal Maso M., Ehn M., Hakola H., Hari P., Hartonen K., Hämeri K., Hölttä T., Junninen H., Järvi L., Kurten T., Lauri A., Laurila T., Lehtipalo K., Lihavainen H., Lintunen A., Mammarella I., Manninen H., Petäjä T., Pihlatie M., Pumpanen J., Rinne J., Romakkaniemi S., Ruuskanen T., Sipilä M., Sorvari S., Vehkamäk, H., Virtanen A., Worsnop D., Kerminen V-M. Finnish Centre of Excellence in Physics, Chemistry, Biology and Meteorology of Atmospheric Composition and Climate Change: Preface, summary and outlook, Boreal Env. Res. 19 (suppl. B), 1, 2014.

8. Kulmala M., Alekseychik P., Paramonov M., Laurila T., Asmi E., Arneth A., Zilitinkevich S., Kerminen V.-M. On measurements of aerosol particles and greenhouse gases in Siberia and future research needs. Boreal Env. Res. 16, 2011, pp. 337-362.

9. Lappalainen H.K., Petäjä T., Kujansuu J., Kerminen V.-M. et al. Pan-Eurasian Experiment (PEEX) - a research initiative meeting the grand challenges of the changing environment of the northern Pan-Eurasian arctic-boreal areas, J. Geography Environment Sustainability, 2, 2014, pp. 13-48.

10. Lappalainen H.K. et al. Pan-Eurasian Experiment (PEEX): System understanding of the Arctic-boreal regions for constructing scenarios and assessments of the future development 
of the Northern Pan-Eurasian environments and societies, Atmos. Chem. Phys., 16, 2016, pp. 14421-14461; doi:10.5194/acp-16-14421-2016.

11. Paris J.-D., Ciais P., Nedelec P., Ramonet M., Golytsin G., Granberg I., Athier G., Boumard F., Cousin J.-M., Cayez G., Stohl A. The YAK-AEROSIB transcontinental aircraft campaigns: new insights on the transport of $\mathrm{CO}_{2}, \mathrm{CO}$ and $\mathrm{O}_{3}$ across Siberia, Tellus B, 60 (4), 2008, pp. 551-568.

12. Sasakawa M., Machida T., Tsuda N., Arshinov M., Davydov D., Fofonov A. Land boundary layer and the lower free troposphere over southern taiga in West Siberia: Long-term records from 2002 to 2011, Journal of Geophysical Research: Atmospheres, 118, 2013, pp. 94899498; doi:10.1002/jgrd.50755.

13. Lenton T.M., Held H., Kriegler E., Hall J.W., Lucht W., Rahmstorf S., Schellnhube H.Jo. Tipping elements in the Earth's climate system, PNAS, 2008, 105 (6), pp. 1786-1793; doi:10.1073 pnas.0705414105.

\section{APPENDIX-1}

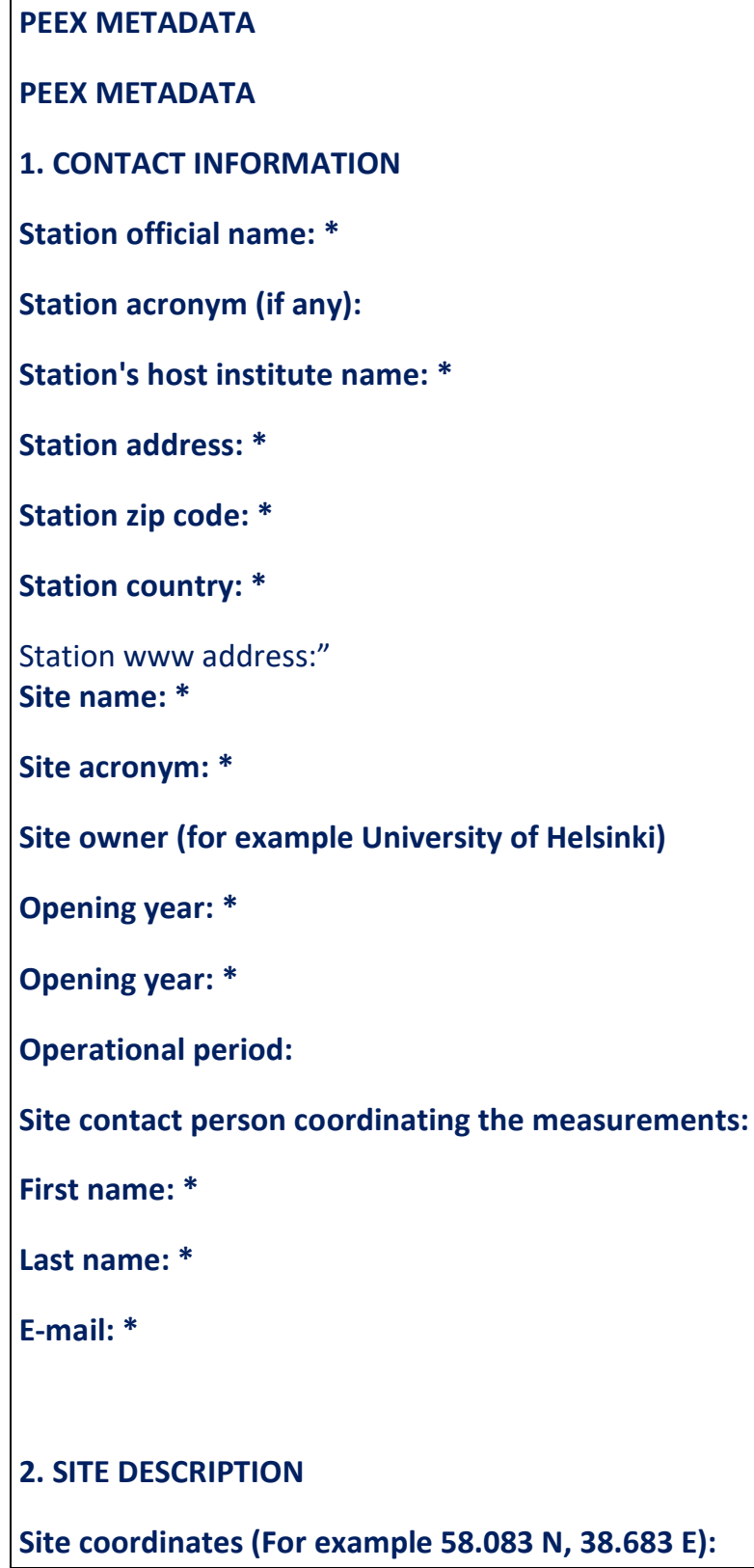

\section{SITE DESCRIPTION}

Site coordinates (For example 58.083 N, 38.683 E): 


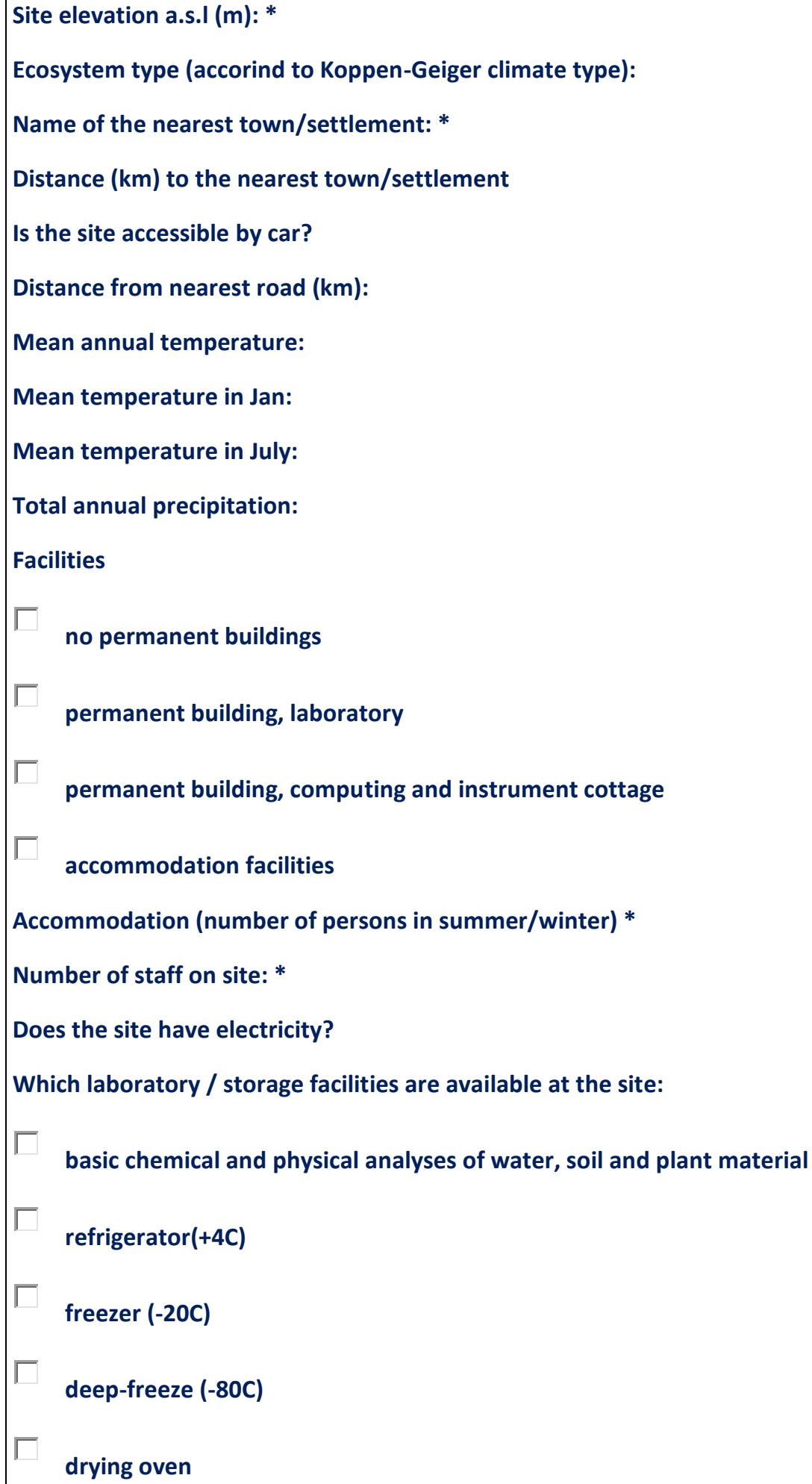




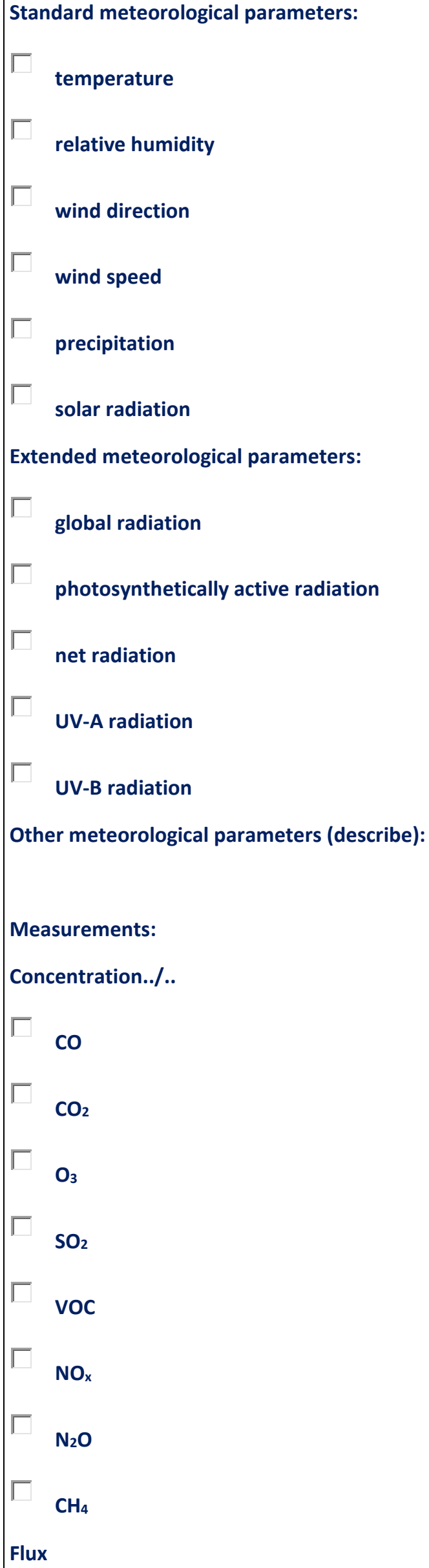




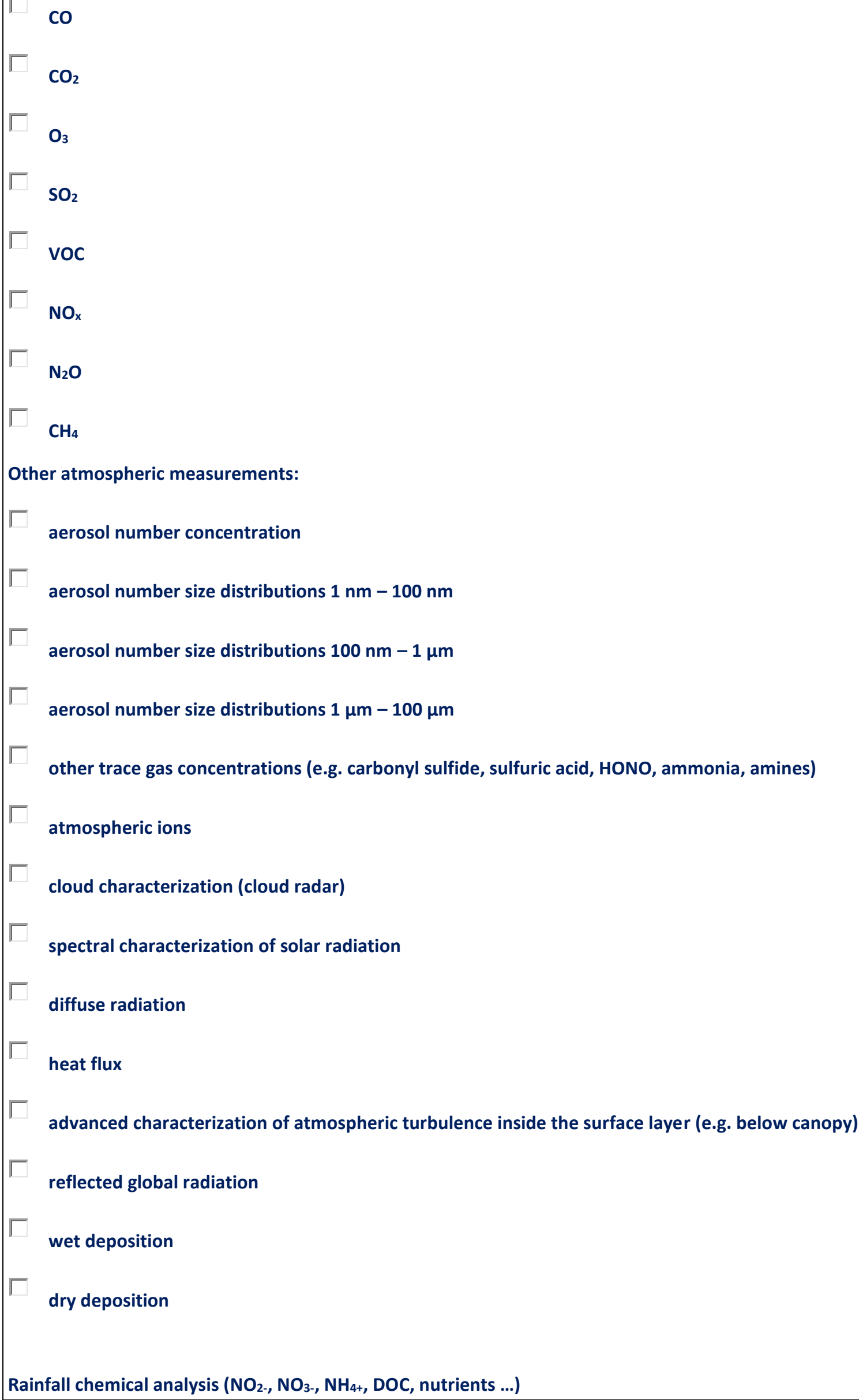


(specify):

Other site-specific features:

hosting intensive field studies

inter-platform calibrations and verifications (in-situ, satellite, airborne)

development of novel instrumentation

$\Gamma$

focused campaigns to determine the connections between the fluxes and environmental and ecosystem factors

Short description of the measurement instrument setup you are using (names/ manufacturer of the instruments)

Short description of the measurement frequency of different parameters (hourly/daily/seasonal/ annual etc.)

Other relevant information on your measurements (for example field campaigns)

(ii) ECOSYSTEM MEASUREMENTS: soils - forest - lakes - urban

Stand history

Stand age (yr):

Soil type

Soil texture

soil water holding capacity (\%)

Hydraulic conductivity (K)

Cation exchange capacity $(\mathrm{cmol}+/ \mathrm{kg})$

pH.

snow depth $(\mathrm{cm})$

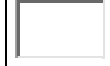

Snow cover duration (months)

Description of ground vegetation (name of species in Latin) 
Description of fire history

Soils

soil bulk density

amount of soil organic matter

soil water content

soil temperature profile

soil nutrient concentrations

soil solution samplings (e.g. DOC, nutrients)

soil chemical characteristics ( $\mathrm{pH}, \mathrm{CEC}, \mathrm{C}$ and $\mathrm{N}$ content)

$\mathrm{CO}_{2}$ surface flux (chamber measurements)

$\mathrm{CH}_{4}$ surface flux (chamber measurements)

$\mathrm{N}_{2} \mathrm{O}$ surface flux (chamber measurements)

VOC surface flux (chamber measurements)

isotopic ratios of carbon in soil organic matter

soil microbiology

soil enzyme concentrations

characteristics of soil organic matter (e.g. lignin, sugars, cellulose, proteins)

belowground biomass

water storage in the soil

snow depth and snow water content

discharge (catchment)

runoff (catchment)

groundwater level 


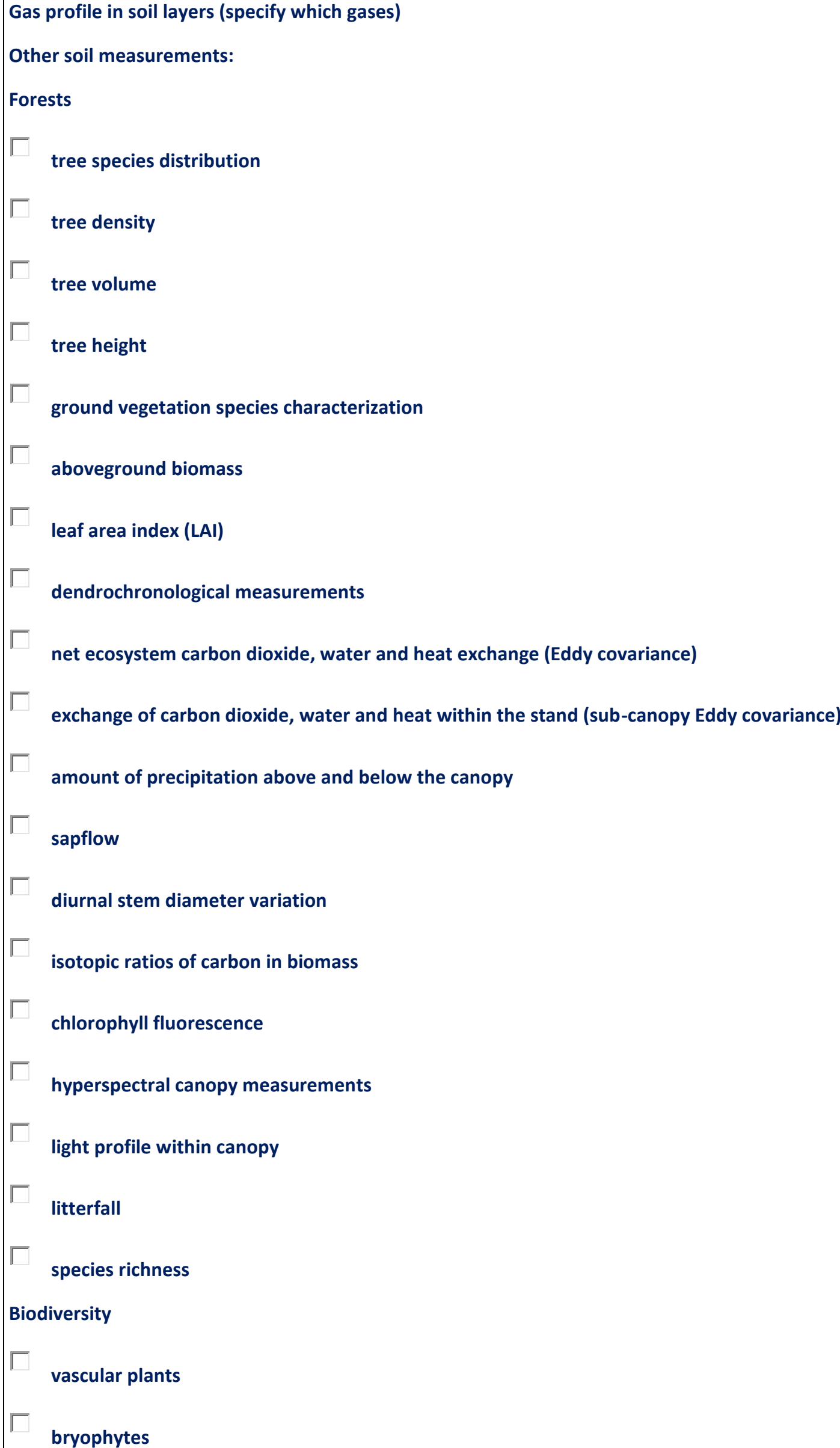




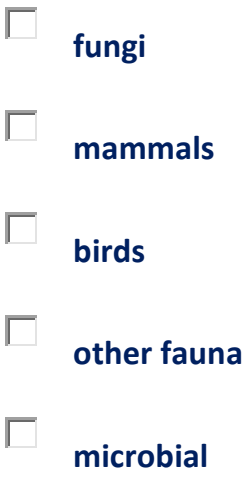

Short description of the measurement instrument setup you are using (names/ manufacturer of the instruments):

Short description of the measurement frequency of different parameters (hourly/daily/seasonal/ annual etc.):

Other relevant information on your measurements (for example field campaigns):

Lakes

$\mathrm{CO}_{2}$ continuous eddy covariance measurements

$\Gamma$

$\mathrm{H}_{2} \mathrm{O}$ continuous eddy covariance measurements

$\mathrm{CH}_{4}$ continuous eddy covariance measurements

PAR in the water

Chamber measurements for $\mathrm{CO}_{2}$

Chamber measurements for $\mathrm{CH}_{4}$

Chamber measurements for $\mathrm{N}_{2} \mathrm{O}$

Gas concentration measurements throughout the water column $\left(\mathrm{CO}_{2} / \mathrm{CH}_{4} / \mathrm{N}_{2} \mathrm{O}\right)$

Continuous $\mathrm{CO}_{2}$ concentration measurements at different depths of the water column

Continuous temperature measurements throughout the water column (thermistor chain)

Continuous measurements for surface water $\mathrm{pH}$

Continuous measurements for surface water oxygen

Continuous measurements for surface water conductivity

Secchi depth determinations

Discrete sampling for water column DOC concentration

Discrete sampling for water column nutrient concentrations 


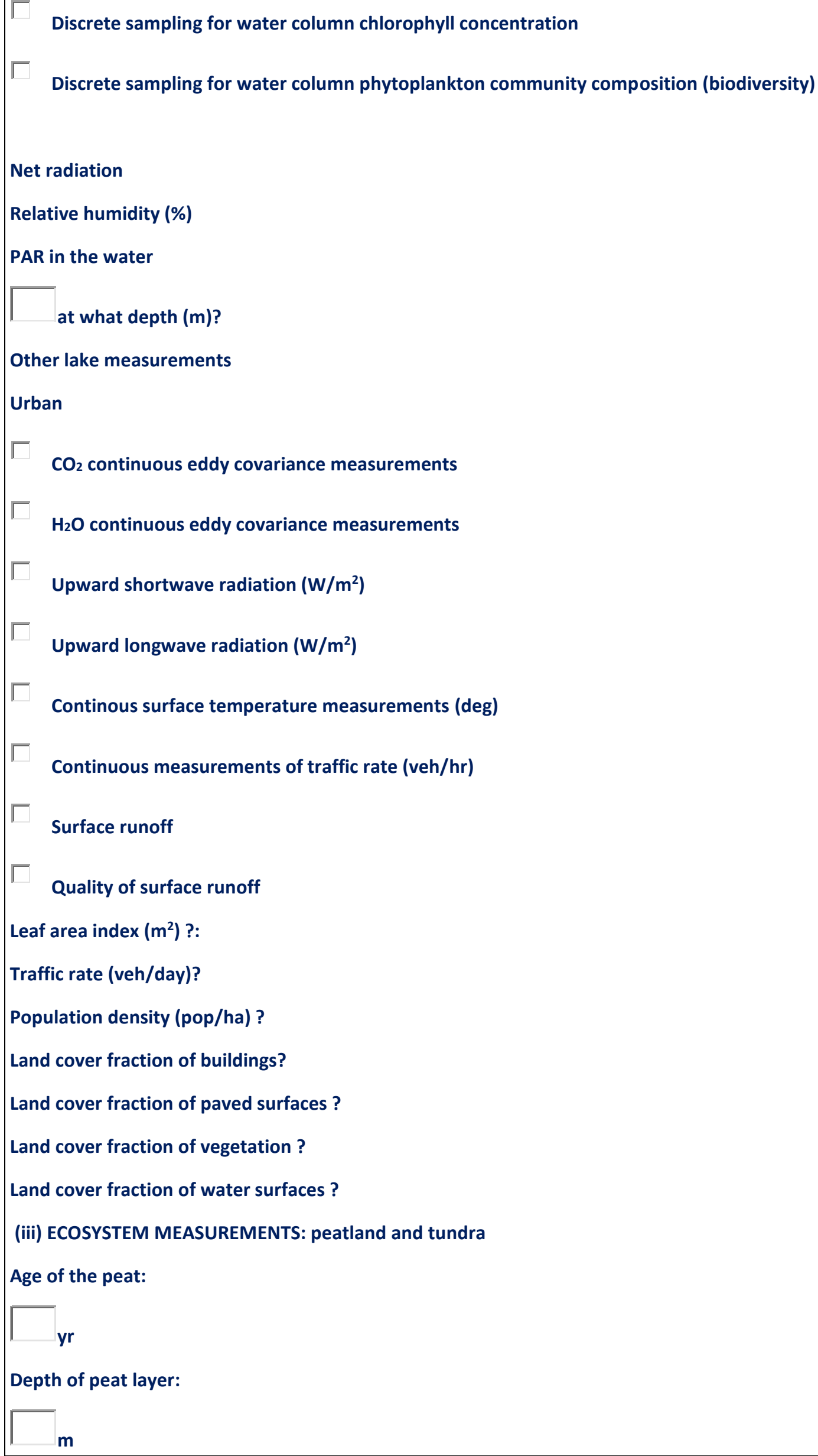


Permafrost depth:

m

Active layer max depth:

m

temperature profiles of the soil/peat layers

soil/peat temperature profile down to the bed rock (bore hole)

soil/peat water content

$\mathrm{CO}_{2}$ surface flux (chamber measurements)

$\mathrm{CH}_{4}$ surface flux (chamber measurements)

$\mathrm{N}_{2} \mathrm{O}$ surface flux (chamber measurements)

VOC surface flux (chamber measurements)

$\mathrm{CH}_{4}$ concentrations in the peat profile

Г

$\mathrm{CH}_{4}$ concentration in the air

isotopic ratios of $\mathrm{CH}_{4}$ in air

isotopic ratios of $\mathrm{CH}_{4}$ in peat

upward and downward net radiation fluxes

upward and downward radiation fluxes

precipitation

water table depth

snow depth and snow water content

discharge (catchment)

runoff (catchment)

nutrient concentrations in peat

carbon and nitrogen concentration in peat 


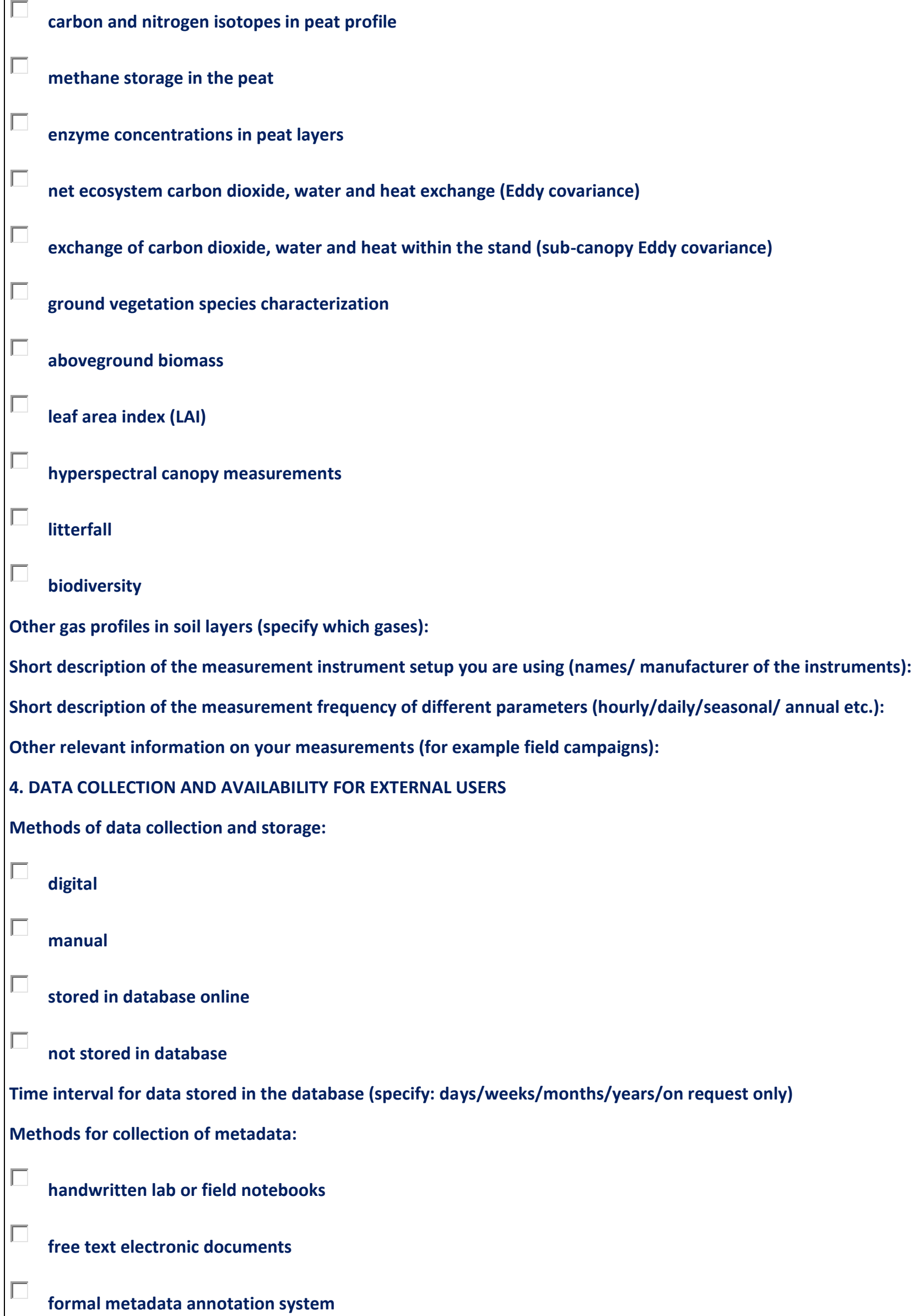




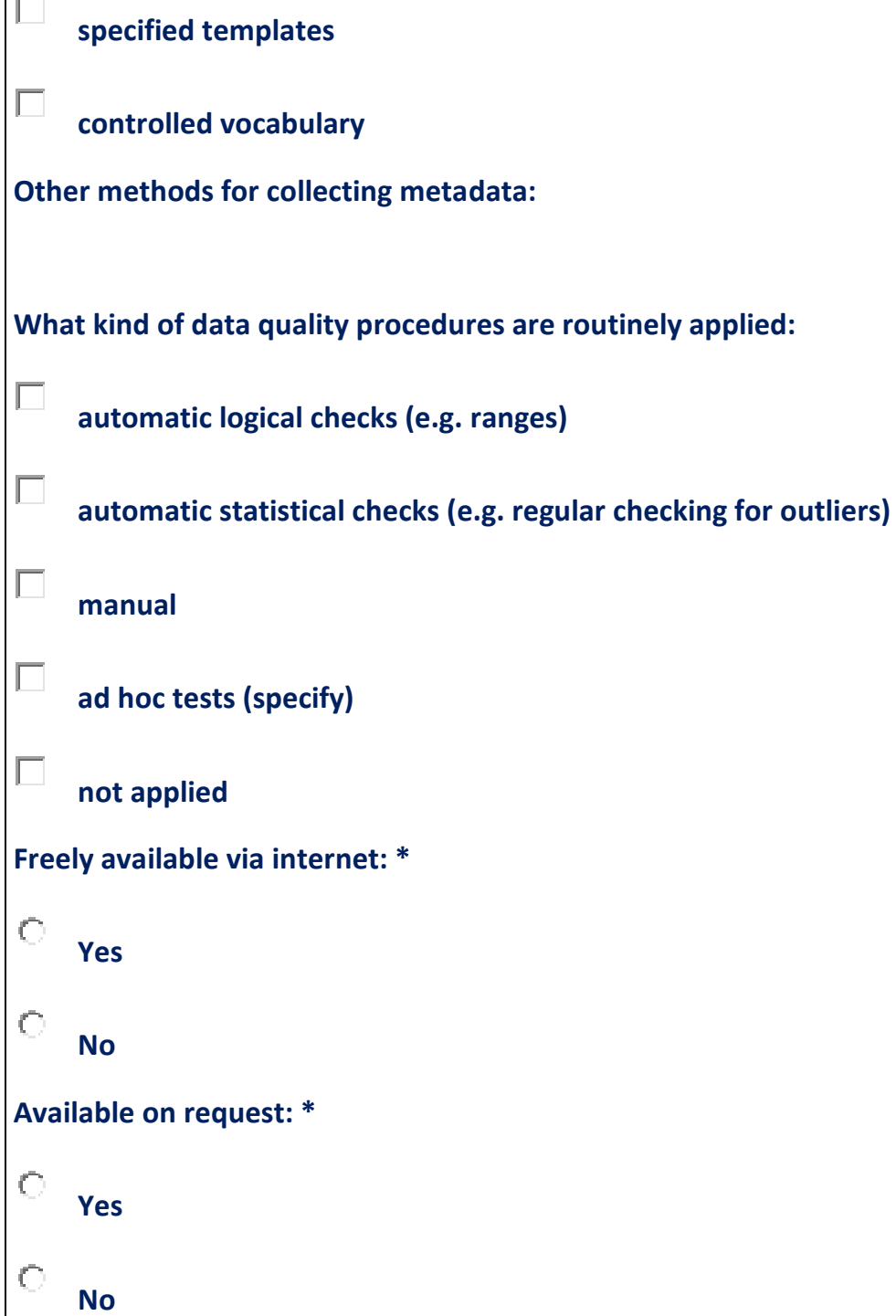

Other methods for collecting metadata:

What kind of data quality procedures are routinely applied:

automatic logical checks (e.g. ranges)

automatic statistical checks (e.g. regular checking for outliers)

manual

ad hoc tests (specify)

not applied

Freely available via internet: *

Y Yes

No

Available on request: *

Y Yes

No

\section{COLLABORATION ACTIVITES AND PARTICIPATION IN NETWORKS}

Names of the national programs or projects the site is participating:

Names of the international programs or projects the site is participating:

Short description of field campaigns: name(s) of the campaign(s), year, measurements performed:

Interested in participating in PEEX RI Preliminary Station network: *

C Yes

C No

Other comments:

\section{DATASET FOR THE PEEX - View}

We are interested in receiving one example of a dataset measured in your station. We would like to include a one month dataset in our PEEX View tool advertising your station. We PEEX demo visualizes the time series for the modeled data vs. observed data. NOTE: You may submit atmospheric, biological or societal datasets. Examples of a data file formats (i) advanced (ii) basic. 
Submit your data for the PEEX View:

file types: $x|s, x| s x$, dat,csv,nas, doc, docx max size:800 KB

Powered by ChronoForms - ChronoEngine.com

Back to Top

(C) 2016 PEEX METADATA

УДК 551.324

DOI: $10.24057 / 2414-9179-2017-1-23-159-171$

\title{
А.В. Погорелов ${ }^{1}$ Е.С. Бойко ${ }^{1}$, Д.А. Петраков ${ }^{2}$ Е.Н. Киселёв ${ }^{1}$ \\ РЕАКЦИЯ ЛЕДНИКА ФИШТ (ЗАПАДНЫЙ КАВКАЗ) НА СОВРЕМЕННЫЕ ИЗМЕНЕНИЯ КЛИМАТА
}

\begin{abstract}
АННОТАЦИЯ
Обобщены данные наблюдений за ледником Фишт - самым западным ледником Кавказа, расположенным на высотах 2450-2750 м. Географическое положение ледника Фишт позволяет считать его одним из наиболее чувствительных к изменениям климата ледников на Кавказе. Источники сведений - схема (1909 г.), аэрофотосъемка (1954 г.), тахеометрическая съемка (1982 г.), воздушное лазерное сканирование (ВЛС) и аэрофотосъемка (2010 г.), съемка с помощью малого беспилотного летательного аппарата (БПЛА) (2015 г.). Установлено, что за 1909-2015 г2. площадь ледника сократилась с 0,9 до 0,5 км², отступание двух языков в плане составило $200 \pm 20$ м (восточный язык) и $350 \pm 20$ м (западный язык). При этом в течение 1982-2010 г2. ледник находился в квазистационарном состоянии. В 20112015 г2. зафиксировано скачкообразное сокращчение размеров ледника. Этому способствовали пониженные суммы осадков в октябре -мае, повышенные температуры воздуха в июне сентябре, существенно меньшие снегозапасы в 2010-2015 г2. в сравнении с периодом 1982-2010 г2. В 2010-2015 г2. среднее значение аблящии оказалось примерно на 800 мм водного эквивалента больше, чем в 1982-2010 г2. По нашим оченкам, если в 1982-2010 г2. средняя годовая аккумуляциия на леднике Фишт составляла около 4500 мм, то в 2011-2015 г2. она уменьшилась до 3900 мм. Одновременно в 2010-2015 г2. годовой баланс массы ледника оказался не менее чем на 1500 мм меньше, чем в 1982-2010 г2.

Полученные результаты позволяют, вкупе с другими сведениями, уточнить внутрирегиональную (Кавказ) изменчивость отклика ледников на современные изменения климата. Апробированные на леднике технологии измерений средствами ВЛС и БПЛА показали их применимость в горных условиях в части высокоточного моделирования ледниковой поверхности и последующих картометрических расчётов.
\end{abstract}

\section{КЛЮЧЕВЫЕ СЛОВА:}

беспилотник, воздушное лазерное сканирование, динамика ледника, Западный Кавказ, изменения климата

\footnotetext{
${ }^{1}$ Кубанский государственный университет; Россия, 350040, Краснодар, ул. Ставропольская, 149; e-mail: pogorelov_av@bk.ru.

2 Московский государственный университет им. М.В. Ломоносова, географический факультет; Россия, 119991 , Москва, Ленинские горы, 1; e-mail: dpetrakov@gmail.com
} 